\title{
A Elevação da Percentagem do Excesso da Arrecadação Estadual e as Necessidades Municipais
}

(Notas à margem do projeto Lot Neto)

\author{
A. Delorenzo Neto \\ (Conselheiro da Associação Brasileira dos \\ Municípios)
}

\section{$\mathrm{O}$}

Estado Federal estabelece ao discriminar competências, ao lado da União Soberana, a autonomia dos Estados e Municípios. Essa autcnomia, evidentemente, nos países pobres como o nosso, não impede, antes estimula e exige um regime de cooperação entre os três níveis da federaçãc, Considerando essa possibilidade de natureza constitucional, pode-se desde logo aquilatar da oportunidade do Projeto de lei n. 373 , de 1955, de autoria do Deputado Domingos Lot Neto, e que dispõe, que a percentagem do excesso da arrecadação estadual de impostos, salvo o de exportação, sôbre o total da receita municipal de qualquer natureza, que o Estado entregará anualmente a cada Município, exceto o da Capital, nos termos das leis n. ${ }^{\circ} 589$, de 31 de dezembro de 1949, e 2063, de 24 de dezembro de 1952, — será de $50 \%$ (cinqüenta por cento) à partir de $10^{\circ}$ de janeiro de 1957 .

Além dos pressupostos doutrinários que legitimam o projeto convem acentuar, êle está fortemente ancorado na Constituição Estadual, cujo artigo 67 estabelece expressamente: "Quando a arrecadação estadual de impostos, salvo o de exportação, exceder em Município que não seja o da Capital o total da receita municipal de qualquer natureza, o Estado atribuir-lhe-á anualmente de trinta a cinqüienta por cento do excesso arrecadado." Este artigo foi regulamentado pela lei n. ${ }^{\circ} 589$, que fixou a percentagem do excesso de arrecadação no mínimo permitido pela Constituição Estadual, isto é, em $30 \%$. Pcrém, o dispositivo constitucional deu ao legislador inteiro arbitrio para fixar a taxa percentual, desde que observados cs seus limites mínimo e máximo. Dessa faculdade se utilizou o autor do Projeto em aprêço, concebendo-o dentro das limitações constitucionais, e em coerência com o espírito municipalista que vem modificando a discriminação financeira a partir de 1946 .

O projeto, aprovado pela Assembléia Legislativa, apesar da sua importância inavaliável não mereceu a aprovação do Governador do Estado, que the opôs veto total. Entre as razões de veto, (1) invoca-se a de que o projeto viria perturbar gravemente as finanças do Estado em processo de recuperamis

(1) in "Diário Oficial do Estado de São Paulo", de 5 de janeiro de 1956. 
ção adiantada, insuficientes ainda diante dos penosos encargos de planejamento administrativo que abrange inúmeras obras de interêsse especificamente municipal. Essas razões podem ser respeitáveis, mas apenas significam um episódio na administração, e de modo algum poderão impedir o curso de uma medida destinada a transformar profundamente a política municipal, constitucionalmente legítima, como a consubstanciada no projeto de lei 373 .

A carência de verbas em que vivem os Municípios é um fato incontestável. Tanto assim que as justificativas da campanha municipalista que se desencandeou no Brasil, a partir de 1946, assentam na análise do problema da desigual repartição das rendas entre os três níveis de govêrno.

Ao lado de uma melhor discriminação de competência, possível em ampla reforma constitucional, os Congressos Nacionais de Municípios vem recomendando medidas financeiras de grande repercussão administrativa, para que melhor sejam assistidos os Municípicis. Assim, nas Cartas de São Vicente e São Lourenço, entre as principais reivindicações aprovadas pelas comissões técnicas se estabeleceram estas: (2)

- Transferência imediata para ${ }^{\circ}$ os Municípios do Impôsto Territorial Rural e $10 \%$ do Impôsto de Consumo.

- Entrega aos Municípios pelo menos de metade da cota de $60 \%$ do Fundo Rodoviário Nacional, que cabe aos Estados.

- Reforma do Artigo 15, item IV, da Constituição Federal, elevandose para $20 \%$ a cota do Impôsto de Renda atribuída aos Municípios.

- Percepção de quarenta por cento no mínimo do total das rendas públicas arrecadadas no país, dentro de prazo razoável e progressivamente, quer mediante outorga de novos tributos, quer pela maior participação das rendas federais e estaduais."

Vê-se pelos itens citados, como nêles perfeitamente se integra o projeto de lei 373 , que visa fortalecer o regime cooperativo do Estado para com os Municípios. Com a rejeição do veto, e conseqüente restauração do projeto terão os Municípios um meio considerável para coordenar as atividades administrativas em regime de planificação integral. Pois, a situação em que se encontram mal lhes permite acudir às exigências de rotina, executando, às mais das vêzes, um programa precário realmente pcuco digno do progresso econômico de São Paulo. Um vasto campo de ação própria está à espera de um impulso decisivc. E o Estado bem poderá ser o propulsor dessas atividades vitais, capacitando o Município para o desempenho da dinâmica administrativa.

Recordemos algumas iniciativas de competência local, perfeitamente realizáveis tendo em vista a metodologia adequada da planificação, mas que exigem investimentos que exorbitam das possibilidades atuais das Prefeituras.

(2) "in" Carta Municipalista de São Vicente, edição do D.A.S.P. Rio, 1953, e Carta de São Lourenço, Separata da "Revista Brasileira dos Municípios", n. ${ }^{\circ} 26$, Rio de Janeiro, 1954. 


\section{Enumeremo-1as:}

- Reorganização geral e racional dos serviços públicos municipais, com o fim de aumentar-lhes a eficiência e o rendimento;

- Criação de serviços de assistência rural;

- Criação de serviços de assistência social;

- Cooperação nos planos de assistência ao menor abandonado;

- Concessão de bolsas de estudos para formação de enfermeiros especializados, para crganizar e dirigir onde não exista assistência médica, enfermarias-modêlo, com salas destinadas a serviços de pronto socorro;

- Extinção de favelas, mocambos e cortiços, como meio de combate à mortalidade infantil, à delinquiência e ao analfabetismo;

- Constituição de um fundo para fins de financiamento dos serviços sociais;

- Auxílio para construção de habitações urbanas e rurais próprias;

- Construção de parques infantis e bibliotecas;

- Instalação de escolas móveis, para alfabetização dos habitantes das zonas rurais;

- Criação de escolas típicas rurais, com sentido profissional, para adolescentes alfabetizados, destinadas a preparar o homem do campo para os encargos da mecanização da lavoura e da agricultura racional;

- Criação de Serviços ou Departamentos de Defesa Vegetal e Animal, bem como a instalação de colônias típicas, granjas cu fazendas-modêlo;

- Instalação de cooperativas de crédito, consumo e distribuição, facilitando, por todos os meios disponíveis, o seu funcionamento;

- Constituição de sociedades de econcmia mista para obtenção do capital necessário à exploração da energia elétrica;

- Organização de serviços volantes de cinema educativo e recreativo para a zona rural, bem como criação de postos volantes de saúde, os quais visitariam as sedes distritais e núcleos de regular densidade demográfica;

- Recuperação social do colono, através de hospitais regionais e pcstos agro-pecuários;

- Delimitação, em cada Município, da zona destinada à criação, a fim de evitar-se a transformação de zona de lavoura em zona de pastagem, o que vem constituindo forte fator de êxcdo rural. minerais;

- Elaboração de planos racionais de aproveitamento de recursos hidra

- Elaboração de plano Diretor, compreendendo além dos estudos sôbre o território, o planejamento de urbanismo da sede e povoados;

- Execução de estudos e levantamentos rigorosos como preliminar básica às providências para a melhoria do padrão de vida das populações, e ainda 
estudos pertinentes à exploraçãc, aproveitamento, conservação e fomento da produção agrícola e industrial. Eis aí um vasto campo de atividades que indicam as tarefas locais peculiares.

Mas o desenvolvimento delas torna-se quase impossível diante da atual falta de recursos. Ora, é certo que à Constituição Estadual cabe proceder à discriminação das rendas em estaduais e municipais, porém, a liberdade da discriminação só é admissível a favor dos Municípios. Não se pode alterar o que está expresso no Artigo 20 da Constituição Federal: o Estado só pode manter o status quo ou conceber mais. Essa a perspectiva que abriu do reerguimento dos municípios paulistas a Constituição Estadual. O projeto Lot Neto, uma vez convertido em lei, será fator de reajustamento dos municípios, que, assim habilitados financeiramente, poderão enfrentar por si próprios cs seus complexos problemas de desenvolvimento. E, a Assembléia Legislativa compensará, aprovando a importante iniciativa, o irregular pagamento das cotas anteriores e a indiferença do Estado mais rico da Federação, que ainda não sistematizou, em plano específico, a assistência técnica aos seus Municípios. (3)

(3) No item 33, da página 28 da Carta de São Vicente se estabeleceu como assunto relevante da competência dos governos estaduais - a organização de planos quadrienais de assistência aos Municípios. Os projetos paulistas criando a cadeira de Direito Municipal e a Secretaria do Interior, jazem esquecidos. 